\title{
IDENTIFIKASI DAN PENANGGULANGAN FAKTOR RESIKO DEFISIENSI VITAMIN D PADA LANSIA DI KOTA MATARAM
}

\author{
Deasy Irawati*1), Ardiana Ekawanti ${ }^{11}$, Gede Wirabuana Yuda ${ }^{1)}$, Gede Palgunadi' ${ }^{2}$ \\ ${ }^{1)}$ Fakultas Kedokteran UNRAM; ${ }^{2)}$ Rumah Sakit Umum Daerah Provinsi NTB \\ ${ }^{1)} \mathrm{Jl}$. Pendidikan No. 37 Mataram; ${ }^{2)}$ Jl. Dasan Cermen Mataram \\ ${ }^{*}$ Alamat korespondensi: deasy15ira@yahoo.com
}

\begin{abstract}
ABSTRAK
Berdasarkan data dari Setiati (2008), defisiensi vitamin D pada lansia di Indonesia menunjukkan bahwa pada setiap 3 lansia terdapat 1 lansia yang beresiko untuk mengalami defisiensi vitamin D. Hal ini sangat vital mengingat lansia memiliki resiko lebih tinggi untuk mengalami defisiensi vitamin $D$. Defisiensi vitamin $D$ pada lansia sering kali tersembunyi di balik keluhan kesehatan lainnya sehingga tidak terdeteksi secara dini. Defisiensi vitamin D pada lansia akan berdampak pada sistem skeletal, kardiovaskuler, pencernaan, syaraf dan imunitas tubuh. Dari hasil penelitian Irawati et al (2018) didapatkan bahwa 4 dari 5 lansia memiliki asupan makanan yang rendah vitamin D. Selain itu, kami juga mengamati adanya faktor resiko terjadinya defisiensi vitamin $\mathrm{D}$ pada populasi target. Tujuan kegiatan pengabdian kepada masyarakat ini adalah untuk mengidentifikasi faktor resiko kekurangan asupan vitamin D dan meningkatkan pengetahuan lansia yang tergabung di dalam Perhimpunan Hari Lanjut Usia Kota Mataram tentang kecukupan vitamin D dan pencegahan defisiensi vitamin D. Metode pelaksanaan kegiatan meliputi skrining faktor resiko defisiensi vitamin $D$ dan penyuluhan kecukupan vitamin D. Materi penyuluhan berupa informasi mengenai sumber vitamin $D$, manfaat dan pentingnya kecukupan vitamin $D$ terhadap pencegahan penyakit skeletal dan non skeletal pada lansia. Hasil skrining faktor resiko defisiensi vitamin $\mathrm{D}$ pada lansia menunjukkan bahwa gangguan penglihatan, demensia dan perasaan khawatir akan jatuh merupakan faktor resiko utama kekurangan asupan vitamin D. Dari kegiatan penyuluhan, tingkat kehadiran peserta tinggi dan terdapat respon aktif dari para peserta saat sesi tanya jawab.

Kata kunci: kecukupan gizi, kota mataram, lansia, vitamin D

\section{PENDAHULUAN}

Dalam 2 dekade terakhir, peningkatan prevalensi defisiensi vitamin D banyak dilaporkan baik oleh negara maju dan negara berkembang. Di Amerika Serikat, 3 dari 4 orang

mengalami defisiensi vitamin D (Ginde, Liu, \& Camargo, 2009). Di Australia, 1 dari 3 orang mengalami kekurangan vitamin $\mathrm{D}$ dengan peningkatan resiko defisiensi pada wanita, lansia, obesitas dan individu dengan aktifitas fisik yang
\end{abstract}


rendah (Daly et al., 2012). Di Asia Tenggara, prevalensi kekurangan vitamin D berkisar dari 30\% - 50\% (Poh et al., 2016). Di Indonesia, 35.1\% lansia yang tinggal di panti sosial (panti jompo) mengalami defisiensi vitamin $D$ (Setiati, 2008).

Sumber utama vitamin D adalah dari paparan sinar matahari, hanya sedikit sumber makanan yang mengandung vitamin $D$ alamiah. Berkurangnya transmisi sinar UVB pada kulit merupakan penyebab utama defisiensi vitamin D. Paparan sinar UVB dipengaruhi oleh jumlah melanin, penggunaan pelindung terhadap sinar matahari seperti tabir surya, musim / iklim, dan budaya. Melanin sangat efisien dalam menyerap sinar matahari dengan panjang gelombang $290-700 \mathrm{~nm}$ termasuk sinar UVB yang bertanggung jawab untuk sintesis previtamin D3 (Chen, Lu, \& Holick, 2010). Dengan kuantitas paparan sinar ultraviolet yang sama, populasi dengan pigmen melanin yang rendah seperti pada ras Kaukasian mengalami peningkatan konsentrasi serum vitamin $D$ namun tidak demikian pada populasi kulit hitam (Clemens, Henderson, Adams, \& Holick, 1982). Penggunaan tabir surya juga mempengaruhi kuantitas sinar UVB yang dapat mengaktifkan provitamin D3. Penggunaan tabir surya SPF 15 akan menyerap 99\% UVB sehingga hal ini akan menurunkan $99 \%$ sintesis vitamin D3 (Matsuoka, Ide, Wortsman, MacLaughlin, \& Holick, 1987). Faktor budaya juga mempengaruhi kejadian defisiensi vitamin D. Budaya seperti mengenakan pakaian yang menutupi permukaan tubuh akan mengakibatkan rendahnya paparan sinar UVB ke kulit (Gannage-Yared, Chemali, Yaacoub, \& Halaby, 2000). Pada lansia, resiko terjadinya defisiensi vitamin $D$ semakin meningkat (Daly et al., 2012). Hal ini dikarenakan dengan meningkatnya usia, kegiatan diluar rumah berkurang sehingga paparan matahari berkurang. Selain itu perubahan fisiologi akibat proses penuaan juga berperan terhadap tingginya kejadian defisiensi vitamin D pada lansia. Penurunan fungsi fisiologi saluran cerna seperti menurunnya sensitivitas indera perasa, indera pembau, kemampuan 
mencerna makanan akibat degenerasi pada gigi geligi juga berkontribusi terhadap kejadian defisiensi vitamin D melalui pengaruhnya terhadap variasi pemilihan makanan (John, Bullock, Brenner, McGaw, \& Scolapio, 2013). Kulit yang mengalami atrofi cenderung memiliki cadangan 7dehidrokholesterol yang lebih rendah sehingga produksi vitamin D3 menurun walau telah mendapat paparan sinar UVB yang cukup. Seorang lansia berusia 70 tahun memiliki kadar 7-dehidrokholesterol sebanyak $25 \%$ dari individu dewasa muda dengan penurunan kapasitas sintesis vitamin D3 sebesar $75 \%$ (Holick \& Chen, 2008). Penurunan fungsi ginjal karena proses penuaan juga menurunkan produksi $1 \alpha, 25$ dihidroksivitamin D $[1 \alpha, 25(\mathrm{OH}) 2 \mathrm{D}]$, vitamin D aktif, oleh ginjal (Chen et al., 2010; Mosekilde, 2005).

\section{Defisiensi vitamin D} akan berdampak pada sistem skeletal dan non skeletal. Pasien dengan defisiensi vitamin $D$ (kadar 25-hidroksi vitamin $D(25(\mathrm{OH}) \mathrm{D})$ kurang dari 50 $\mathrm{nmol} / \mathrm{L})$ memiliki peningkatan turnover tulang, penurunan massa tulang dan gangguan mineralisasi (Rizzoli et al., 2013). Selain itu defisiensi vitamin $D$ juga berhubungan dengan berbagai penyakit kronis seperti diabetes tipe 1, Crohn's disease, penyakit infeksi, dan kardiovaskular (Holick, 2007, 2012; Holick \& Chen, 2008; Wang et al., 2008).

Dari penelitian kami sebelumnya (Irawati et al, 2018), didapatkan $>80 \%$ lansia yang menjadi populasi target memiliki kecukupan vitamin $D<80 \%$ AKG. Selama penelitian tersebut, kami juga mengamati kegiatan lansia di luar rumah terbatas dan sebagian besar lansia menggunakan pakaian yang menutupi permukaan tubuh. Hal ini merupakan faktor resiko terjadinya defisiensi vitamin $D$ mengingat bahwa sumber utama vitamin $D$ adalah sinar ultraviolet B (UVB). Berdasarkan permasalahan di atas, maka solusi yang ditawarkan adalah identifikasi faktor resiko defisiensi vitamin $D$ dan penyuluhan tentang kecukupan vitamin $D$, tanda dan gejala defisiensi vitamin $D$ dan pencegahannya pada lansia. Terkait dengan temuan 
tersebut, kami bermaksud makronutrien dengan 24-hours food mengadakan skrining kekurangan asupan vitamin $D$ dan penyuluhan tentang kecukupan vitamin D dan pencegahan defisiensi vitamin D. Kegiatan ini sangat bermanfaat untuk menambah kegiatan promotif berupa peningkatan pengetahuan pada lansia di Mataram.

\section{METODE KEGIATAN}

Dalam kegiatan pengabdian kepada masyarakat ini, terdapat 2 sub kegiatan yakni skrining faktor resiko kekurangan asupan vitamin D dan penyuluhan. Skrining faktor resiko defisiensi vitamin D meliputi asupan vitamin $D$, tinggal sendiri atau tidak, persepsi responden tentang status malnutrisi, gangguan penglihatan, konsumsi obat psikoaktif, depresi, demensia, riwayat jatuh, luka di kulit akibat tekanan, penggunaan alat bantu jalan, perasaaan takut jatuh, patah tulang dan penggunaan suplemen tulang. Metode yang digunakan adalah penilaian asupan recall dan Vitamin $\mathrm{D}$ status predictor (VDSP) oleh enumerator gizi melalui kegiatan wawancara. Kuesioner VDSP telah divalidasi (Annweiler et al., 2017). Penyuluhan disampaikan melalui media demonstrasi. Materi yang disampaikan adalah mengenai sumber vitamin $D$, manfaat dan pentingnya kecukupan vitamin $D$ terhadap pencegahan penyakit skeletal dan non skeletal pada lansia. Sasaran kegiatan ini adalah lansia yang tergabung di Perhimpunan Hari Lanjut Usia di Kota Mataram.

\section{HASIL DAN PEMBAHASAN}

Kegiatan ini didahului dengan penggalian data asupan makanan para lansia yang berpartisipasi dalam program ini oleh enumerator gizi yang telah dilatih. Dari hasil wawancara, data yang didapat diolah dengan menggunakan program Nutrisurvey. Sebanyak 40 lansia berpartisipasi dalam program ini. 


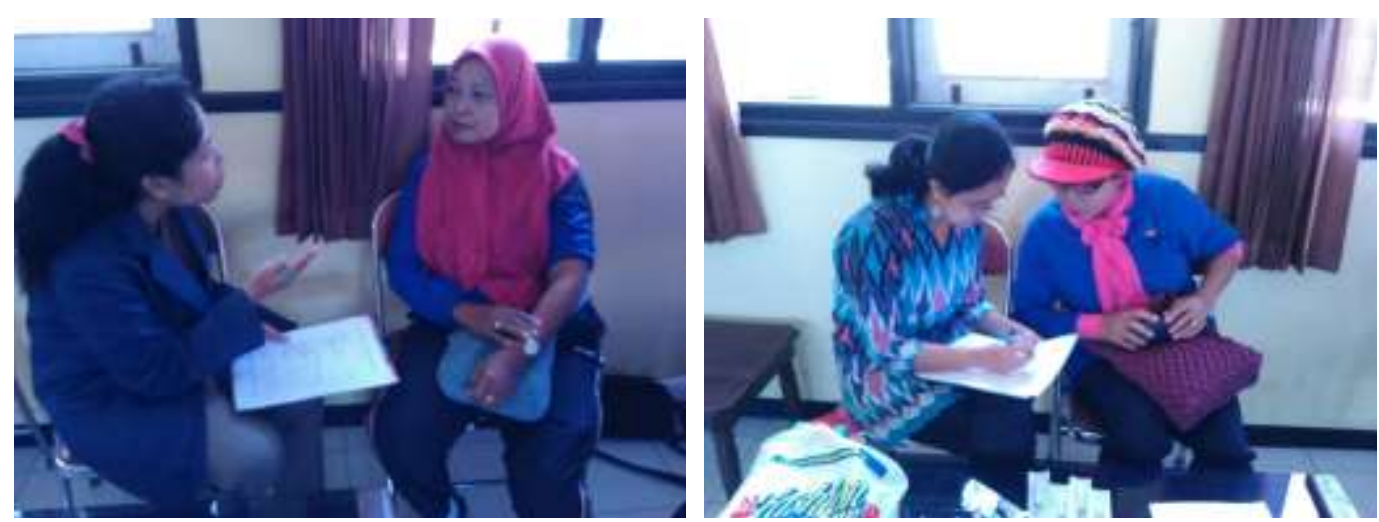

Gambar 1. Proses skrining faktor resiko defisiensi dan asupan vitamin D.

Dari 40 peserta yang AKG vitamin D yang dianjurkan. berpartisipasi dalam kegiatan Berdasarkan hasil skrining faktor pengabdian kepada masyarakat ini resiko, didapatkan bahwa gangguan (Gambar 1), sebanyak 85\% lansia penglihatan, dementia dan perasaan memiliki AKG vitamin D kurang dari takut jatuh merupakan faktor resiko $80 \%$. AKG vitamin D rata-rata adalah kekurangan asupan vitamin D yang $41 \%$, nilai ini sangat rendah daripada utama pada responden kami (Tabel 1). Tabel 1. Pemetaan faktor resiko kekurangan asupan vitamin $D$

\begin{tabular}{lcc}
\hline \multicolumn{1}{c}{ Faktor resiko } & Iya (\%) & Tidak (\%) \\
\hline Komorbid & 27.3 & 65.9 \\
Jumlah konsumsi obat [(median (min - max)] & \multicolumn{2}{c}{$2(1-5)$} \\
Tinggal sendiri & 20.5 & 79.5 \\
Malnutrisi & 13.6 & 81.8 \\
Gangguan penglihatan & 77.3 & 22.7 \\
Konsumsi obat psikoaktif & 2.3 & 95.5 \\
Depresi & 13.6 & 79.5 \\
Dementia & 56.8 & 40.9 \\
Riwayat jatuh & 40.9 & 51.9 \\
Luka di kulit akibat tekanan & 18.2 & 75 \\
Penggunaan alat bantu jalan & 6.8 & 93.2 \\
Takut jatuh & 79.5 & 20.5 \\
Fraktur & 0 & 100 \\
Penggunaan suplemen untuk kesehatan tulang & 20.5 & 79.5 \\
\hline
\end{tabular}

Menindaklanjuti hal tersebut, kami mengadakan sosialisasi hasil dan penyuluhan kecukupan vitamin D pada lansia pada hari Selasa, 16 Oktober 2018. Penyuluhan dilakukan di Aula Balai Sosial Mandalika di Mataram 124

Available online : http://abdiinsani.unram.ac.id 
yang dihadiri oleh 51 peserta PHLU (Gambar 2). Materi penyuluhan berupa sumber vitamin $D$, manfaat dan pentingnya kecukupan vitamin $D$ terhadap pencegahan penyakit pada lansia dan gejala defisiensi vitamin D. Selama kegiatan penyuluhan, peserta tampak antusias dan memperhatikan isi materi penyuluhan. Kegiatan penyuluhan berlangsung selama kurang lebih 60 menit. Di akhir sesi penyuluhan, terdapat sesi tanya jawab terkait materi yang disampaikan. Sebanyak 6 pertanyaan yang diajukan oleh para peserta diantaranya yakni sinar ultraviolet, waktu dan lama berjemur yang optimal, konsumsi minyak ikan, makanan yang mengandung vitamin $D$, hubungan antara penggunakan busana muslim dengan defisiensi vitamin $D$, dan pemenuhan kebutuhan vitamin D pada penderita diabetes.

\section{Pelaksanaan}

kegiatan

pengabdian kepada masyarakat ini tidak terlepas dari beberapa kendala. Adapun kendala yang dijumpai selama proses kegiatan adalah pengaturan waktu wawancara dan gangguan memori yang dapat mempengaruhi proses penggalian data responden.

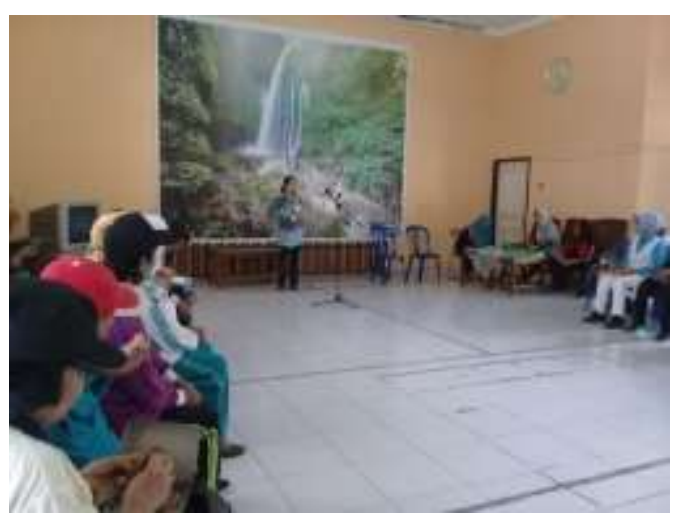

Gambar 2. Penyuluhan pencegahan kekurangan asupan vitamin D.

\section{KESIMPULAN DAN SARAN}

Kekurangan asupan vitamin D dialami oleh $85 \%$ lansia yang berpartisipasi di program pengabdian kepada masyarakat ini. Skrining faktor resiko menunjukkan bahwa gangguan penglihatan, demensia dan perasaan takut jatuh merupakan faktor resiko kekurangan asupan vitamin D yang utama pada responden kami. Kegiatan penyuluhan tentang kecukupan vitamin $D$ dihadiri oleh mayoritas peserta PHLU dan mendapat respon yang antusias dari peserta. Menindaklanjuti kebermanfaatan dari program ini, perlu dilakukan kegiatan pengabdian kepada masyarakat sejenis secara rutin. 


\section{UCAPAN TERIMA KASIH}

Terima kasih diucapkan oleh

tim pengabdian kepada Universitas

Mataram yang telah mendanai

kegiatan ini dengan dana DIPA BLU

Universitas Mataram tahun anggaran

2018. Ucapan terima kasih juga

ditujukan kepada Ketua dan anggota

PHLU Kota Mataram yang telah

bersedia menjadi responden serta

kepada Kepala Balai Lanjut Usia

Mandalika yang telah memfasilitasi

kegiatan pengabdian kepada

masyarakat ini.

\section{DAFTAR PUSTAKA}

Annweiler, C., Kabeshova, A., Callens, A., Paty, M. L., Duval, G. T., \& Holick, M. F. 2017. Selfadministered Vitamin D Status Predictor: Older adults are able to use a selfquestionnaire for evaluating their vitamin D status. PLOS ONE, 12(11), e0186578.

Chen, T. C., Lu, Z., \& Holick, M. F. 2010. Photobiology of Vitamin D. In Vitamin D: Physiology, Molecular Biology, and Clinical Applications (pp. 35-60). Totowa, NJ: Humana Press. Clemens, T. L., Henderson, S. L., Adams, J. S., \& Holick, M. F. 1982. Increased skin pigment reduces the capacity of skin to synthesize vitamin $\mathrm{D}$. The Lancet, 319(8263), 74-76.
Daly, R., Gagnon, C., Lu, Z., Magliano, D., Dunstan, D., Sikaris, K., Zimmet, P. Z., Ebeling, P. R., Shaw, J. E. 2012. Prevalence of vitamin $D$ deficiency and its determinants in Australian adults aged 25 years and older: a national, population based study. Clinical Endocrinology, 77(1), 26-35. Gannage-Yared, M. H., Chemali, R., Yaacoub, N., \& Halaby, G. 2000. Hypovitaminosis $D$ in a sunny country: relation to lifestyle and bone markers. $J$ Bone Miner Res, 15(9), 18561862.

Ginde, A. A., Liu, M. C., \& Camargo, C.

A. 2009. Demographic Differences and Trends of Vitamin D Insufficiency in the US Population, 1988-2004. Archives of Internal Medicine, 169(6), 626-632.

Holick, M. F. 2007. Vitamin D Deficiency. New England Journal of Medicine, 357(3), 266-281.

Holick, M. F. 2012. Evidence-based Dbate on health benefits of vitamin D revisited. Dermatoendocrinology, 4(2), 183-190.

Holick, M. F., \& Chen, T. C. 2008. Vitamin D deficiency: a worldwide problem with health consequences. The American Journal of Clinical Nutrition, 87(4), 1080S-1086S.

Irawati, D., Ekawanti, A., Josafat, A. 2018. Pemetaan Profil Gizi dan Faktor Resiko Malnutrisi pada Lansia. Laporan Penelitian. Universitas Mataram, NTB

John, B. K., Bullock, M., Brenner, L., McGaw, C., \& Scolapio, J. S. 
2013. Nutrition in the elderly. frequently asked questions. American Journal of Gastroenterology, 108(8), 1252-1266.

Matsuoka, L. Y., Ide, L., Wortsman, J., MacLaughlin, J. A., \& Holick, M. F. 1987. Sunscreens suppress cutaneous vitamin D3 synthesis. J Clin Endocrinol Metab, 64(6), 1165-1168.

Mosekilde, L. 2005. Vitamin D and the elderly. Clin Endocrinol (Oxf), 62(3), 265-281.

Poh, B. K., Rojroongwasinkul, N., Nguyen, B. K., Sandjaja, Ruzita, A. T., Yamborisut, U., Hong, T. N., Ernawati, F., Deurenberg, P., Parikh, P. 2016. 25hydroxy-vitamin $D$ demography and the risk of vitamin D insufficiency in the South East Asian Nutrition Surveys (SEANUTS). Asia Pac J Clin Nutr, 25(3), 538-548.

Rizzoli, R., Boonen, S., Brandi, M. L., Bruyère, O., Cooper, C., Kanis,
J. A., Kaufman, J. M., Ringe, J. D., Weryha, G., Reginster, J. Y. 2013. Vitamin D supplementation in elderly or postmenopausal women: a 2013 update of the 2008 recommendations from the European Society for Clinical and Economic Aspects of Osteoporosis and Osteoarthritis (ESCEO). Current Medical Research and Opinion, 29(4), 305-313.

Setiati, S. 2008. Vitamin D status among Indonesian elderly women living in institutionalized care units. Acta Med Indones, 40(2), 7883.

Wang, T. J., Pencina, M. J., Booth, S. L., Jacques, P. F., Ingelsson, E., Lanier, K., Benjamin, E. J., D'Agostino, R. B., Wolf, M., Vasan, R. S. 2008. Vitamin D Deficiency and Risk of Cardiovascular Disease. Circulation, 117(4), 503-511. 